\title{
Clathrin Heavy Chain 1
}

National Cancer Institute

\section{Source}

National Cancer Institute. Clathrin Heavy Chain 1. NCI Thesaurus. Code C97414.

Clathrin heavy chain 1 (1675 aa, $192 \mathrm{kDa}$ ) is encoded by the human CLTC gene. This protein plays a role in formation of cellular vesicles, receptor internalization and receptormediated endocytosis. 